DOI: $10.17569 /$ tojqi.288860

Araştırma Makalesi

\title{
Yabancı Dil Olarak İngilizce Öğrenimine Yönelik E-Materyal Tasarımında Harmanlanmış Bir Mentörlük Uygulaması
}

\author{
Alev Ateş Çobanoğlu ${ }^{1}$, Zehra Esin Yücel ${ }^{2}$, Okşan Uzunboylar ${ }^{3}$, Beril Ceylan ${ }^{4}$
}

Öz

Yeni bir dili öğrenme süreci, yabancı dil öğretmenlerinin öğrenenlerin kendilerini derse vermelerini sağlamaya uğraştıkları zorlu bir süreçtir ve şüphesiz öğretim teknolojisi bu konuda ilginç ve yaratıcı yollar bulmada onlara yardım edebilmektedir. Çalışmanın amacı, öğretmen eğitiminde h-mentörlük uygulamasının sonuçlarını paylaşarak h-mentörlük uygulama süreçlerini daha etkin hale getirmeye yönelik önerilere ulaşmaktır. Çalışmada, Ege Üniversitesi Yabanc1 Diller Yüksekokulunda öğrenim gören, orta seviye öncesindeki İngilizce hazırlık öğrencilerine yönelik e-materyal seti geliştirilmiştir. Harmanlanmış bir mentörlük uygulaması olan bu işbirlikli çalışmada, iki Bilişim Teknolojileri (BT) uzmanı koordinatör, beş İngilizce okutmanı mentör, 46 BT öğretmen adayı ise menti olarak yer almıştır. Mentörlük sürecinde, planlama, uygulama ve değerlendirme adımları izlenmiştir. Uygulama, 2015-2016 akademik yılı güz döneminde, Ege Üniversitesi, Eğitim Fakültesi, Bilgisayar ve Öğretim Teknolojileri Eğitimi Bölümü derslerinden Eğitimde Materyal Tasarımı ve Kullanımı kapsamında gerçekleşmiştir. Bu kısa dönemli, formal uygulamanın sonunda, İngilizce mentörlerinin ve

\footnotetext{
${ }^{1}$ Yard.Doç.Dr., Ege Üniversitesi, Eğitim Fakültesi, BÖTE Bölümü, alev.ateş@ege.edu.tr

${ }^{2}$ Okt., Ege Üniversitesi, Yabancı Diller Yüksekokulu, zehra.esin.yucel@ege.edu.tr

${ }^{3}$ YL öğrencisi, Ege Üniversitesi, Fen Bilimleri Enstitüsü, BÖTE Bölümü, oksan214@gmail.com

${ }^{4}$ Arş.Gör.Dr., Ege Üniversitesi, Eğitim Fakültesi, BÖTE Bölümü, beril.ceylan@ege.edu.tr

Geliş tarihi: 19.08.2016, Kabul tarihi: 25.01.2017
} 
mentilerin harmanlanmış mentörlük uygulamasına ilişkin görüşleri anket aracıllğıyla elektronik olarak toplanmıştır. Durum çalışması olarak desenlenen bu çalışmada, doküman analizi yapılmıştır. Verilerin çözümlenmesinde betimsel analiz ve içerik analizi teknikleri kullanılmıştır. Çalışmanın öne çıkan bulguları arasında; İngilizce mentörlerinin bir ekip arkadaşı olarak öğretmen adaylarına yardımcı ve yol gösterici olmaları ve mesleki anlamda da içerik uzmanı olarak sorumluluk almaları yer almaktadır. Harmanlanmış mentörlük uygulaması, hem mentör hem de mentiler tarafindan genel anlamda olumlu karşılanmaktadır. Sonuçlar, öğretmen eğitiminde disiplinler arası, harmanlanmış öğrenmeye dayalı çalışmalar yürütmek isteyenler için cesaret vericidir. Bu çalışmada mentör-menti etkileşimini güçlendirerek hedefine ulaştığı düşünülen harmanlanmış mentörlük uygulamalarının, öğretmen eğitiminde yaygınlaştırılması önerilmektedir.

Anahtar Sözcükler: E-mentörlük, harmanlanmış mentörlük, öğretmen eğitiminde e-mentörlük, İnilizce öğrenimi, e-materyal geliştirme 


\section{Giriş}

Sosyo-kültürel gelişim kuramına göre sosyal etkileşim, öğrenme sürecinde önemli bir yere sahiptir. Yakınsal gelişim alanı kavramı çerçevesinde Vygotsky, çocukların kendilerinden bilgi ve deneyim olarak üstün olan yetişkin ya da akranları ile sosyal etkileşimleri sonucunda bilgilerini oluşturduklarını ya da yapılandırdıklarını ifade etmektedir (Yurdakul, 2015). Bu bağlamda mentörlük de kendinden daha az deneyime ve beceriye sahip bir kişiye, daha deneyimli ve becerikli bir kişinin gerek kişisel gerekse mesleki alanda öğretim, eğitim ve danışmanlık rolüyle yardım etmesi olarak tanımlanır (Bradbury ve Koballa, 2008; Gormley, 2008; Anderson ve Shannon, 1998). Mentörlük süreci içerisinde bilgi ve deneyimi yeterli olmayan, işe yeni başlamış, yönlendirilmeye ihtiyacı olan ve mentöre emanet edilen kişiye ise menti denilmektedir (Gu ve Day, 2012; Hudson, 2016; Özdemir, 1997).

Mentörlük sürecinde mentörler bilgi, beceri ve deneyimlerini menti ile paylaşmaya açık, gerektiğinde mentiyi psikolojik olarak destekleyen ve onu güdüleyen olmalıdır. Bunun yanında, mentinin edimini (performansını) gözden geçiren, olumlu ve olumsuz yönleri ile yorumlayan, firsat ve tehditler konusunda öneriler getiren, mentinin her zaman rahat erişebileceği ve her konuda danışabileceği, gerektiğinde ona rol model olan bir konumda olması beklenir. Daha önemlisi mentörün, mentiyi yeti ve yetenekleri doğrultusunda yönlendiren kişiler olması gerektiği belirtilmektedir (Kuzu, Kahraman ve Odabaşı, 2012). Ayrıca, iyi bir mentörün samimi, dürüst, destekleyici, anlayışlı, bağlı, yardımsever, prensipli, saygılı ve yetkilendirmeye hevesli, açık, işbirliğini destekleyen, bilgilendirici gibi özellikler taşıdığı belirtilmiştir (Kılınç ve Alparslan, 2014).

Teknolojik gelişmeler sayesinde mentörler ile mentiler arasındaki iletişim, coğrafi bölgelerle sınırlı kalmamaktadır. Bu bağlamda, menti ile mentörün bir araya gelerek etkileşimlerini İnternet ortamında gerçekleştirdiği mentörlük türü, elektronik mentörlük, e-mentörlük, telementörlük, sibermentörlük ya da sanal mentörlük olarak nitelenmektedir (Brescia, 2002; Kocabaş ve Yirci, 2011; Knouse, 2001; O’Neil ve Gomez 1996; Single ve Muller, 1999). İnternet, e-posta ve çevrimiçi tartışma gruplarının kullanılmasıyla, mentörlüğe gereksinim duyan gençler, zaman ve mekân engellerini aşıp, e-mentör desteği alabilmektedir (Hasselbring ve Glaser, 2000). Örneğin; e-posta aracılığıyla iletişim kurulduğunda, sözlü iletişimde olduğu 
gibi kişiler anında yanıt verme baskısından kurtulmakta; iletilerin üzerinde daha fazla düşünerek yazabilme olanağı kazanmaktadırlar (Single ve Muller, 1999). Küreselleşen dünyamızda e-mentörlük, ülkesi ya da yaşayıp büyüdüğü şehri dışında görev yapmak zorunda kalan yönetici ve öğretmenler için de bir çözüm yöntemi olarak görülmektedir (Bakioğlu ve Göğüş, 2010). Oturduğu şehir ya da ülke dışında görev yapanlar için e-mentörlük; psikososyal destek yönünden stresi azaltmaya, sosyalleşmeye, bireysel gelişime ve kültürlerarası eğitime destek sağlamaya yardımcı olmaktadır (Wood, 2007). Bunlara ek olarak, e-mentörlüğün diğer özellikleri arasında; anında gerçekleştirilebilmesi, uygulama olanaklarının daha fazla olması, bireye özel olması, eş zamanlı ya da eş zamansız bilgi ve deneyim paylaşımına olanak sağlaması gibi yararları da bulunmaktadır (YTÜ-KM, 2016).

E-mentörlüğün tüm bu katkılarının yanında süreçte birtakım zorluklarla da karşılaşılmaktadır. Özellikle yalnızca güçsüz bir bağlılıkla oluşturulmuş sanal ilişkilerin olduğu e-mentörlük ilişkilerinde çok sayıda yanlış anlaşılma oluşmaktadır. Süreçte bilgisayar teknolojilerinin kullanılması, bilgisayar okuryazarlığını gerekli kılmakta, teknolojik sorunlar yaşanabilmektedir. Ek olarak, e-mentörlük uygulamasının gerçekleştiği ortamlarda, daha önce hiç tanışmamış kişilerin buluşması mentör ile menti arasında samimiyet oluşmasını zorlaştırmaktadır (Wood, 2007). Tümüyle elektronik ortam üzerinden yürütülen mentörlük uygulamalarındaki bu tür iletişim sorunlarına karşılık, yüz yüze iletişim unsuru taşıyan harmanlanmış mentörlük uygulamalarının süreci daha etkili hale getirebileceği düşünülmektedir.

Mentörlük sürecinin elektronik araçlar üzerinden yürütülmesi olarak ele alınabilecek ementörlük ya da sanal mentörlük kapsamında, mentör ve mentinin yalnızca elektronik olarak haberleşmediği, aynı zamanda yüz yüze görüşmeler de yaptığı mentörlük uygulamaları ise harmanlanmış ya da hibrit mentörlük uygulamalarıdır. Harmanlanmış e-mentörlük ya da kısaca h-mentörlük uygulaması örneği olarak Murphy (2011), işletme öğrencileri ve mezunlarıyla yaptığı uygulamada, e-posta ve telefon yanı sıra yüz yüze görüşmeler aracılığıyla da danışmanlık sürecini sürdürmüştür. Buna göre harmanlanmış mentörlük, hem mentör hem de mentiler üzerinde olumlu katkılarda bulunmuştur. Mentörlerin bu şekilde daha fazla danışmanlık yapma olanağı bularak memnuniyetlerinin arttığı, mentilerin de hem mesleki hem de psikososyal açıdan daha fazla destek alabildikleri, kariyerlerini daha iyi planladıkları ve ementörleriyle ilişkilerini sürdürmeyi istedikleri belirtilmiştir. 
E-mentörlük ve h-mentörlükle ilgili alanyazında, bu uygulamalara ilişkin daha çok olumlu ve az oranda olumsuz etkiler rapor edilmiştir. E-mentörlüğün olumlu özellikleri arasında; mentörler ile mentiler arasındaki lojistik sınırlamaları giderdiği (Thompson vd., 2010); mentörlerin deneyimlerini aktararak mentilerini destekledikleri ve iletişim becerilerini geliştirdiği (Arkün Kocadere ve Kızılkaya Cumaoğlu, 2015; Lamb ve Aldous, 2012) belirtilmektedir. Buna ek olarak, Türkiye'de il eğitim denetmen ve yardımcılarının mesleki açıdan başarılarını artırdığı (Özdemir ve Özan, 2013), mesleki yardım ve rehberlik, inceleme ve soruşturma, liderlik, danışmanlık ve araştırmacılık rollerini betimlediği (Kılınç ve Alparslan, 2014) görülmektedir. E-mentörlüğün olumsuz özellikleri ise teknik sorunların yaşanabildiği, bilgisayar erişiminde zorlanıldığı ve kişisel tercihleri karşılamadığı (Cothran vd., 2009) şeklinde sıralanmıştır. H-mentörlük uygulamalarında ise daha fazla danışmanlık yapma olanağı bulan mentörlerin memnuniyetlerinin arttığ 1 , mentilerin de hem mesleki hem de psikososyal açıdan daha fazla destek alarak kariyerlerini daha iyi planladıkları belirtilmiştir (Murphy, 2011). Ayrıca h-mentörlük uygulamaları, e-mentörlüğün sınırlılıklarından belirtilen iletişim sorunlarına da çözüm üretmektedir (Thompson vd., 2010).

\section{Araştırmanın Amacı ve Önemi}

Alanyazında da görüldüğü gibi, h-mentörlük modeliyle daha etkili iletişim kurulabilmekte, bilgi ve deneyim paylaşımları esnek ve verimli bir şekilde yürütülebilmektedir. Bununla birlikte, Türkiye'de öğretmen adaylarının katıldığı e-mentörlük ya da h-mentörlük uygulamalarının yeterince olmayışı, ayrıca mentör ve menti gözüyle h-mentörlük sürecinin etkililiği konusunda alanyazındaki boşluğu işaret etmektedir. Bu bakımdan hem yüz yüze hem de çevrimiçi ortamın üstün yönlerinin birlikte kullanıldığı bir harmanlanmış öğrenme ortamında, öğretim üyesi yanı sıra alan uzmanlarının da mentörlüğüyle öğretmen adaylarının bilgi ve becerilerini geliştirmek, h-mentörlüğü işe koşmak çalışmanın çıkış noktasıdır. Arkün Kocadere ve Kızılkaya Cumaoğlu'nun (2015) BT öğretmen adaylarıyla yaptığı e-mentörlük uygulaması bu çalışmaya ilham veren özellikler taşımakla birlikte, BT öğretmenlerini İngilizce okutmanlarıyla harmanlanmış mentörlük uygulaması kapsamında biraraya getiren bu çalışma, öğretmen eğitiminde h-mentörlük modelinin bir uygulaması olması yönünden alanyazına katkı getirmektedir. 
Bu çalışmada, BT öğretmen adaylarının yabancı dil olarak İngilizce öğrenimine yönelik emateryal geliştirme süreçlerinde İngilizce okutmanı olan mentörlerinden destek almalarına ve İngilizce mentörlerinin h-mentörlük sürecine ilişkin görüşlerini betimlenmektedir. Çalışmanın amacı, öğretmen eğitiminde yürütülen bir h-mentörlük uygulamasının sonuçlarını paylaşarak h-mentörlük uygulama süreçlerini daha etkin hale getirmeye, daha başarılı uygulamalar planlamaya ve yaygınlaştırmaya yönelik önerilere ulaşmaktır. $\mathrm{Bu}$ çalışmanın ayrıca hmentörlerden beklentileri ortaya koyacağı ve bu konuda yapılacak çalışmalara örnek teşkil edeceği düşünülmektedir.

Araştırmada özellikle menti rolündeki öğretmen adaylarının bakış açılarından h-mentörlük uygulamasına yönelik değerlendirme bulgularına ulaşmaya odaklanılarak şu alt amaçları şu şekildedir:

1. Mentilere göre h-mentörlerin özellikleri nelerdir?

2. Mentilerin h-mentörlük uygulamasına ilişkin görüşleri nelerdir?

3. Mentörlerin h-mentörlük uygulamasına ilişkin görüşleri nelerdir?

\section{Yöntem}

Durum çalışması olarak desenlenen bu çalışmada, Stake'in tepki değerlendirme modelinde belirttiği gibi çalışma grubunda yer alan paydaşların incelenen duruma ilişkin farklı bakış açıları ortaya konmaya çalışılmıştır. Durum çalışmasının amacı; bir ya da birkaç durumu, tek bir katılımcıyı ya da döküman setini kendi sınırları içerisinde çözümlemektir (Bogdan ve Biklen, 2007; Yıldırım ve Şimşek, 2008). Bütüncül tek durum olarak desenlenen bu çalışmada, gerçekleşen h-mentörlük uygulaması incelenen durumu oluşturmakta; h-mentörlerin özellikleri, mentilerin ve mentörlerin h-mentörlük sürecine ilişkin görüşleri ise bu durumun öğeleri olarak ele alınmıştır. Mentörlük uygulama süreci aşağıda belirtilen planlama, uygulama ve değerlendirme adımlarında detaylandırılmaktadır. Bu amaçla, h-mentörlük sürecinin sonunda araştırmacılar tarafindan hazırlanan, kapalı ve açık uçlu sorular içeren formlar aracılığıyla hem BT öğretmen adaylarının hem de İngilizce mentörlerinin uygulamaya ilişkin görüşleri alınmıştır. Bu açıdan çalışmanın veri seti; mentilerin ve mentörlerin bildirimlerine dayanan dokümanlardır. Durum çalışmalarında ideal olarak çok boyutlu veri toplanması (görüşme, gözlem, doküman analizi) (Yıldırım ve Şimşek, 2008) önerilmekle birlikte, bu 
çalışmanın veri kaynağının paydaşların kendi bildirimlerine dayalı görüşlerini içeren dokümanlar olması, çalışmanın bir sınırlılığı olarak ele alınmaktadır.

\section{Çalışma Grubu}

İki BT uzmanının koordinatörlüğünde yürütülen çalışmada, amaçlı örnekleme yöntemiyle belirlenen çalışma grubu içerisinde mentör olarak beş İngilizce okutmanı ve menti olarak 46 BT öğretmen adayı yer almaktadır. Tümü kadın olan mentörlerden Mentör-1 kurumunda 17 yıllık mesleki deneyime sahiptir. 23 y1llık deneyimi olan Mentör-2, çeşitli bilimsel projelerde de yer almıştır. Bununla birlikte, Mentör-3'ün 6 yıl, Mentör-4'ün 18 yıl, Mentör-5'in ise 16 yıl mesleki deneyimi bulunmaktadır. Buna göre, mentörlerin kurumlarındaki mesleki deneyimleri ortalama 16 yıldır. Tüm mentörler, bilgisayar ve internet erişimine sahiptir. Mentörlerin üçü bilgisayar bilgileri konusunda kararsız olmakla birlikte biri kendini yetersiz görmekte, biri ise bilgisayar bilgisinin çok iyi olduğunu ifade etmektedir. Mentörlerin tamamı ingilizce öğretiminde teknoloji entegrasyonu konusuna ilgi duymaktadırlar ve kendilerini bu alanda geliştirmek istemektedirler. Daha önce herhangi bir mentörlük deneyimi olmayan ancak teknoloji konusunda kendilerini geliştirmek isteyen tüm mentörler ve ingilizce konusunda bilgi ve becerilerini geliştirmek isteyen mentiler çalışmaya katılma konusunda hem istekli hem de gönüllü olduklarını belirtmişlerdir. Çalışma grubundaki mentiler yani BT öğretmen adayları, Ege Üniversitesi, Eğitim Fakültesi, Bilgisayar ve Öğretim Teknolojileri Eğitimi (BÖTE) bölümünde ikinci sınıfa devam eden 32 erkek, 14 kadın öğrencidir. Bir öğrenci dışında tümünün bilgisayara erişimi, dört öğrenci dışında tümünün ise İnternet erişimi bulunmaktadır.

\section{E-mentörlük Süreci}

Kısa dönemli ve formal yapıda gerçekleştirilen e-mentörlük sürecinde, yapılandırılmış ementörlük modeli (Single ve Single, 2005) doğrultusunda planlama, uygulama ve değerlendirme adımları izlenmiştir.

\section{a) Planlama}

Çalışmanın, 2015-2016 akademik yılı Güz döneminde, Ege Üniversitesi, Bilgisayar ve Öğretim Teknolojileri Eğitimi Bölümü ikinci sınıf dersi olan Eğitimde Materyal Tasarımı ve 
Kullanımı dersinde gerçekleşmesi kararlaştırılmıştır. Bu dersin kuramsal bölümünde; eğitimde teknoloji ve materyal kullanımının önemi ve nedenleri, öğretim materyali seçimi, görsel tasarım ilkeleri, öğretimde kullanılan görsel, işitsel ve görsel-işitsel araçlar, eğitimde bilgisayar, İnternet ve iletişim teknolojileri ile uzaktan eğitim uygulamalarının yeri ve önemi konusunda temel bilgi ve becerilerin kazandırılması amaçlanmaktadır (EÜ-EBYS, 2016). Dersin uygulama bölümünde ise, BT öğretmen adayları işbirlikli gruplar halinde çalışarak, görsel tasarım ilkelerine uygun ve farklı türlerde öğretim materyalleri geliştirmektedirler. Dersin hedefleriyle örtüşecek şekilde İngilizce okutmanlarını bilişim teknolojileri kullanmaya teşvik ederek İngilizce dijital ders materyalleri üretmek ve BT öğretmen adaylarının İngilizce bilgilerini artırmak hedeflenmiştir. Buna göre, BT öğretmen adaylarının menti, İngilizce okutmanlarının ise mentör olmaları kararlaştırılmıştır.

Çalışmada, tüm mentörlerin ve mentilerin iletişim ve etkileşimlerini artırarak birlikte daha verimli çalışabilmeleri amacıyla harmanlanmış mentörlük modelinin uygulanması planlanmıştır. Buna göre, haftalık olarak yüz yüze görüşmelerin yanı sıra, sanal ortam da işe koşularak Edmodo çevrimiçi sosyal ağı sayesinde, bilgi paylaşımının desteklenmesi ve etkileşimlerin belirli bir platform üzerinden düzenli yürütülmesi öngörülmüştür. Kuzu, Kahraman ve Odabaşı'nın (2012) belirttiği gibi, e-mentörlük sürecinde düzenlenebilecek ortak alan, mentör alanı ve menti alanı şeklindeki çevrimiçi alanlar; mentör, menti ve varsa koordinatörleri buluşturmaktadır. Bu çalışmada da Edmodo üzerinde, hem mentör hem de mentilerin birarada olduğu derse ait bir ortak sanal alan, mentörlere ve koordinatörlere ait ayrı bir sanal alan yaratılmıştır. Edmodo, BT mentörleri ve öğretmen adayları tarafından önceden kullanılan bir platform olmakla birlikte, Edmodoyu daha önce kullanmamış olan İngilizce mentörlerine BT mentörleri tarafından uygulama öncesinde bilgilendirme yapılmıştır. Bu ortamın yanı sıra, menti ve koordinatörlerin haftalık ders saatlerinde yüz yüze oturumlarda; menti ve mentörlerin ise birlikte kararlaştırdıkları yüz yüze danışma saatlerinde bir araya gelmeleri planlanmıştır.

\section{b) Uygulama}

Uygulama aşamasında, BT öğretmen adayları, İngilizce mentörleriyle orta seviye öncesindeki İngilizce hazırlık öğrencilerine yönelik animasyon, etkileşimli görsel ve eğitsel video türlerinde e-materyaller geliştirmişlerdir. Öğretmen adayları toplam 12 küçük grup halinde, 
birer İngilizce mentörüyle çalışmışlardır. Her İngilizce mentörüne iki ya da üç grubun danışmanlığı atanmıştır. 14 haftalık uygulama sürecinde, İngilizce okutmanları ders içeriklerinin oluşturulması ve öğrencilerin eğitsel videolarındaki senaryolarının yazımı ve sözcük telaffuzları konusunda hem çevrimiçi ortamda hem de yüz yüze toplantılarda mentörlük yapmışlardır.

\section{c) Değerlendirme}

Uygulamanın amaca ulaşıp ulaşmadığına ilişkin değerlendirme bulguları, Stake'in belirttiği gibi bireylerin farklı bakış açılarını ortaya koymak açısından (Fitzpatrick, Sanders ve Worthen, 2004) katılımcı görüşleri doğrultusunda belirlenmeye çalışılmıştır. Bu amaca yönelik oluşturulan mentör ve menti anketleri aracılığıyla değerlendirme verileri toplanmıştır.

\section{Veri Toplama Araçları}

BÖTE alanından üç uzmanın görüşlerine başvurularak son şekli verilen veri toplama araçları şunlardir:

\section{BT öğretmen adayı anketi}

Araştırmacılar tarafından hazırlanan bu formda, kişisel bilgi soruları da dahil olmak üzere açık uçlu ve evet/ hayır türünde toplam 11 soru bulunmaktadır. Bu sorular arasında, öğrencilerin kişisel bilgilerine yönelik bilgisayar ve internet erişim durumlarını soran soruların yanı sıra, üç dereceli türde "Materyal geliştirme çalışmalarınızda danışman hocalarınızın olmasının katkısını puanlayınız." ve açık uçlu türde "Danışman hocalarınızın ödevlerinize katkılarını belirtiniz." şeklinde sorular yöneltilmiştir.

\section{İngilizce mentörü anketi}

Araştırmacılar tarafından hazırlanan bu formda, kişisel bilgi soruları da dahil olmak üzere açık uçlu ve evet/ hayır türünde toplam 10 soru bulunmaktadır. Bu sorular arasında, okutmanların kişisel bilgilerine yönelik bilgisayar ve internet erişim durumlarını soran soruların yanı sıra, üç dereceli türde "Danışmanları olarak BÖTE öğrencileri ile birlikte çalışma yapmayı nasıl 
değerlendiriyorsunuz?” ve açık uçlu türde "EMTK dersinde yapılan bu işbirlikli çalışmaların katkılarını belirtiniz." şeklinde sorular yöneltilmiştir.

\section{Verilerin Çözümlenmesi}

Çalışmanın veri setini dokumanlar oluşturmaktadır. Elektronik olarak toplanan veriler, yine elektronik iki farklı belgeye kaydedilmiştir. Buna göre veri seti; öğrenci anketine verilen 17 sayfalık ve mentör anketine verilen beş sayfalık olmak üzere toplam 22 sayfadan oluşan dokümanlardır. Yıldırım ve Şimşek’e (2013) göre doküman analizi, araştırılması belirlenen bir konu ya da olgu hakkında bilgi içeren yazılı materyallerin çözümlenmesidir. Betimleme, analiz ve yorumlama aşamalarının izlendiği nitel verilerin çözümlenmesi sürecinde, veriler iki araştırmacı tarafından içerik çözümlemesine tâbi tutulmuştur. Veri setinin tamamı, iki araştırmacı tarafından üçer kez tümüyle okunmuş ve gerekli bölümler çok kez tekrar okunduktan sonra, bir veri çözümleme planı hazırlanmıştır. Yurdakul'un (2008) belirttiği gibi tümevarımcı bir yaklaşımla süreçte ön hazırlık, nitel verilerin kodlanması, temalara ulaşma, veriyi örgütleme, nitel bulguları yorumlama ve raporlaştırma yapılmıştır.

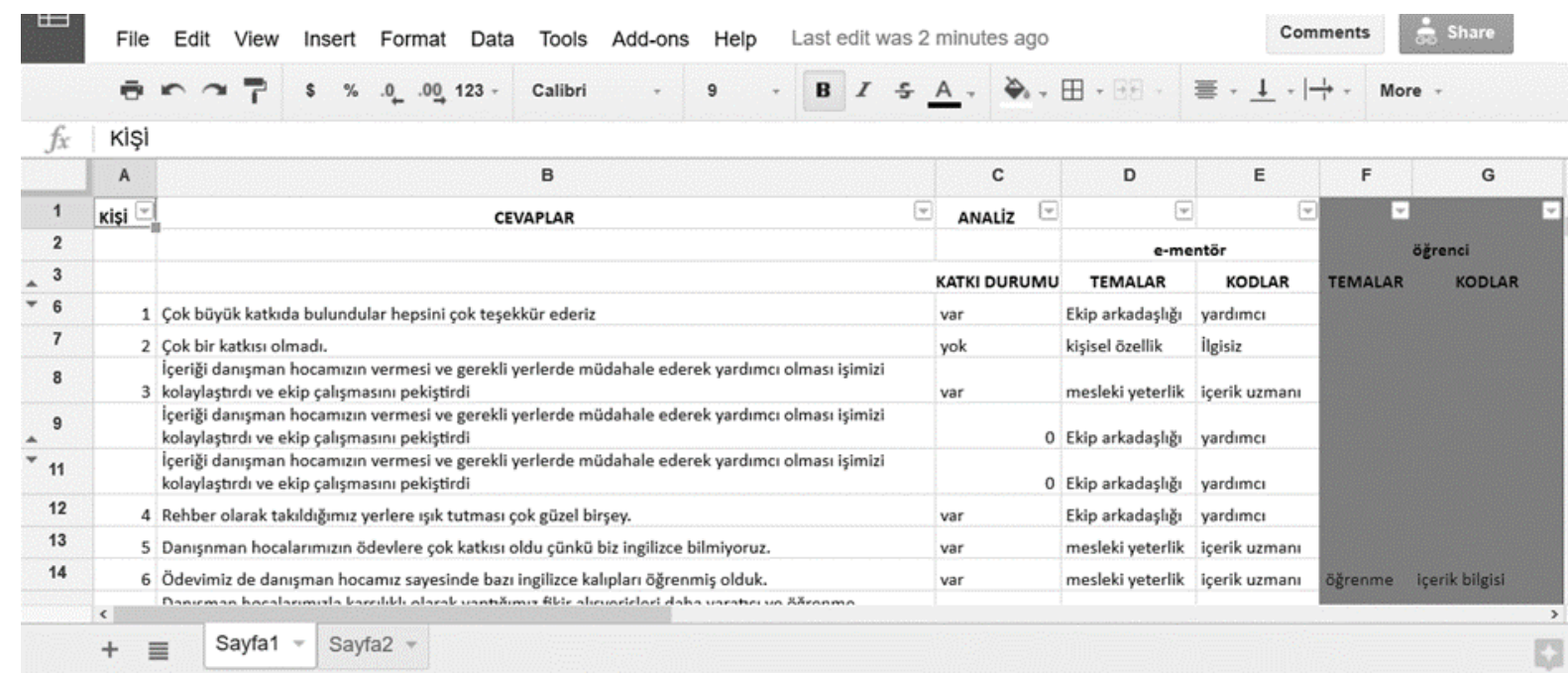

Şekil 1. Veri çözümlemesinin yapıldığı e-tablodan örnek bir gösterim

Yıldırım ve Şimşek'in (2008) önerdiği gibi, tematik kodlama yaparak verileri düzenleyebileceği bir sistem oluşturan araştırmacılar bu amaçla elektronik tablolama programı kullanmışlardır. Şekil 1'de bir bölümü görüldügü gibi, veri çözümleme ve raporlaştırma sürecinde araştırmacılar, bulut sistemi aracılığıyla ortak bir elektronik alanda birlikte çalışma 
olanağ bulmuşlardır. Son aşamada ise bu sisteme göre elde edilen veriler belli olgulara göre tanımlanıp yorumlandıktan sonra okuyucular tarafından rahat anlaşılır bir dille sunulmuştur.

\section{Nitel Bulguların Geçerlik ve Güvenirliğine Yönelik Önlemler}

Nitel araştırmaya konu olan olgu ya da olayla ilgili bütüncül bir resim oluşturabilmek için araştırmacı elde ettiği verileri ve ulaştığı sonuçları doğrulamasına yardımcı yöntemler (çeşitleme, katılımcının doğrulaması, meslektaşın doğrulaması, vd.) kullanmalıdır (Yıldırım ve Şimşek, 2008). Nitel boyuta yönelik geçerlik ve güvenirlik önlemleri (Bogdan ve Biklen, 2007; Creswell, 2003) şunlardır: Verileri ayrıntılı rapor ederek sonuçlara nasıl ulaşıldığının açıklanması; araştırmacıların süreçteki rollerini betimlemesi; farklı bakış açılarını yansıtması ve verileri başka bir uzmanın daha kodlaması. Nitel veri setinin tamamı, program geliştirme alan uzmanı olan ikinci kodlayıcı tarafından da okunarak yeniden çözümlenmiştir. Araştırmacı, ikinci kodlayıcı ile bir araya gelerek tüm nitel çözümlemeleri gözden geçirdikten sonra bulguları raporlaştırmıştır. Araştırma etiği açısından, araştırmanın amaçlarının sözel ve yazılı olarak ifade edilmesi ve bireyin kimliği, kişisel bilgi ve elde edilen verilerin gizli tutulması şeklinde önlemler alınarak katılımcı bireylerin haklarının korunması amaçlanmıştır.

\section{Araştırmacıların Rolleri}

Çalışmada görev alan araştırmacılar arasında BÖTE bölümünden iki öğretim üyesi ve bir yüksek lisans öğrencisi ile bir okutman yer almaktadır. BÖTE öğretim üyelerinden birisi dersin ve çalışmanın yürütücüsü ve veri çözümlemede ikinci kodlayıcı; yüksek lisans öğrencisi uygulama ve raporlaştırmada yardımcı; okutman ise diğer okutmanların mentörü olarak uygulama sürecini kolaylaştırıcı olarak görev almışlardır. Araştırmacılar arasındaki diğer BÖTE öğretim üyesi ise verileri çözümlemiştir. 13 y1llık mesleki deneyimi olan yürütücü öğretim üyesi, çalışmanın gerçekleştirildiği ders olan Eğitimde Materyal Tasarımı ve Kullanımı dersini dokuz yıldır vermekte olup, Edmodo ile sanal sınıf yönetimi konusunda da beş y1llik deneyime sahiptir. 


\section{Bulgular ve Yorum}

Araştırmanın bulguları, alt amaçlar doğrultusunda BT öğretmen adaylarının h-mentörlerin özelliklerine ilişkin görüşleri ile gerek BT öğretmenleri gerekse İngilizce okutmanlarının hmentörlük uygulaması hakkındaki görüşlerini içermektedir.

\section{Mentilerin Mentörlerin Özellikleri Hakkındaki Görüşleri}

Uygulamaya katılan öğretmen adaylarının 37'si $(\% 80,4)$ h-mentörlüğün materyal geliştirme çalışmalarına katkı sağladığını belirtirken, dört öğretmen adayı ise katkı sağlamadığını belirtmiştir. Beş öğretmen adayı ise bu konuda görüş bildirmemiştir.

İlk olarak, öğretmen adaylarının mentörleri hakkındaki görüşleri incelendiğinde ise h-mentör özelliklerini açıkladıkları görülmektedir. Verilerin çözümlenmesi sonucunda ortaya çıkan temalar ve kategoriler Tablo 1'de görülmektedir.

Tablo 1

Veri çözümleme sonucunda oluşturulan temalar ve kategoriler

\begin{tabular}{lll}
\hline Tema & Kategoriler & $f$ \\
\hline \multirow{3}{*}{ 1. Ekip arkadaşı̆̆ğ } & $\bullet$ Yardımcı & 14 \\
& $\bullet$ Yol gösteren & 11 \\
& $\bullet$ İşirlikli çalışan & 4 \\
2. Mesleki yeterlik & $\bullet$ Fikir veren & 3 \\
& $\bullet$ İcerik uzmanı & 17 \\
& $\bullet$ Öğretmenlik becerisi & 5 \\
3. Kişisel özellikler & $\bullet$ İletişime açık & 5 \\
& $\bullet$ İlgili & 4 \\
& $\bullet$ İlgisiz & 4 \\
\hline
\end{tabular}

Tablo 1 incelendiğinde öğretmen adaylarının h-mentör özelliklerini üç ana tema altında ve dokuz kategoride ifade ettikleri görülmektedir. En çok değinilen kategorilerin sırasıyla içerik uzmanı, yardımcı olma ve yol gösteren özellikleri olduğu belirlenmiştir. 
H-mentör özelliklerinden ekip arkadaşlığı teması yardımcı, yol gösteren, fikir veren ve işbirlikli çalışan alt kategorileriyle incelenmiştir. Öğretmen adayları e-mentörlerinin yardımcı olduklarını şu şekillerde ifade etmişlerdir:

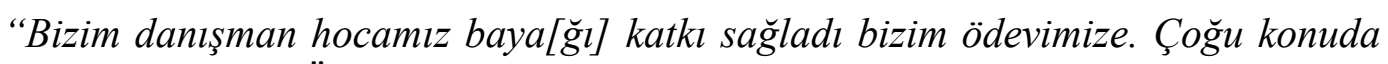
yardımcı oldu. ” [Öğrenci Anketi-16]

“Neredeyse \%80 ini hocalarımız sayesinde yaptık.” [Öğrenci Anketi-23]

"Hazırladı̆̆ımı materyallerde eksik olduğumuz kisımlarda eksiklerimizi tamamladılar." [Öğrenci Anketi-25]

"Danışman hocalarımız să̆ olsunlar en az bizim kadar hatta belki de zaman zaman bizden daha fazla emek harcadılar." [Öğrenci Anketi-31]

Öğretmen adaylarının ifade ettiği bir diğer özellik ise yol gösterici olmalarıdır. Bu konudaki görüşler “Konunun anlaşılması için yol gösterici oldular ve gayet başarılı oldu.” [Öğrenci Anketi-20] ve "Hazırladı̆̆ımız ögrenme materyallerinin hepsinde bizi yönlendirdi ve [bize] rehberlik etti..." [Öğrenci Anketi-26] olarak örneklendirilmiştir.

Öğretmen adaylarının vurguladığı bir diğer özellik ise işbirlikli çalışma olarak belirlenmiştir. "Beraber uyumlu halde çalıştık.", [Öğrenci Anketi-16] görüşü ve "Karşılıklı etkileşimlerle, çalışmalarımızda hocamızın büyük katkıları oldu.”, [Öğrenci Anketi-26] ifadeleri ile bu görüşlerini desteklemişlerdir. Mentörlerin fikir veren özelleri ise "Danışman hocalarımızla karşılıklı olarak yaptığımız fikir alışverişleri daha yaratıcı ve öğrenme açısından kalıcı olabilecek materyaller ortaya çıkarmamıza çok büyük bir katkı sağladı̆̆ı düşüncesindeyim.”, [Öğrenci Anketi-7] ve “Bize içerik ve fikir olarak da yardım etti.”, [Öğrenci Anketi-17] ifadeleriyle belirtilmiştir. Buna göre, öğretmen adayları mentörleri ekip arkadaşı olarak; yardım eden ve yol gösteren olmalarının yanında fikir veren ve işbirliği içerisinde çalışan bireyler olarak tanımlamışlardır. Mentörlerin yardımcı olma ve yol gösterme özelliklerine vurgu yapmaktadirlar.

H-mentör özelliklerinden mesleki yeterlik teması içerik uzmanı ve öğretmenlik becerisi kategorileri altında açıklanmıştır. Öğretmen adayları mentörlerinin içeriklerin hazırlanması konusunda yardımcı olduklarını ifade etmişlerdir:

“İngilizce kısmında direkt sorup öğrenebileceğimiz bir hocanın bulunması yapılan işlemleri hızlandırdı." [Öğrenci Anketi-8] 
"Sonuçta İngilizce çok hakim olmadiğımız bir dil bu yüzden içerik hazırlamada çok yardımcı oldu." [Öğrenci Anketi-12]

"Yoğun olmasına rağmen elinden geldiğince materyal için gereken içerikleri bize erken ulaştırmaya çalıştı." [Öğrenci Anketi-24]

"Kullanacă̆ımız ortamı, materyalleri vb. işsimize yarayacak tüm gerekenleri bize o să̆ladı." [Öğrenci Anketi-38]

Bununla birlikte mentörlerin sahip oldukları becerilerini paylaşarak mentilerine öğretimsel destek verdikleri de görülmektedir. Öğretmen adayları "Öğretmenlik tecrübelerinden yararlanarak yararlı materyaller elde ettik." [Öğrenci Anketi-26] ve "Gerekli yerlerde sorulara verdiği açıklayıcı cevaplar konunun ilerlemesine olumlu katkı sağllyor." [Öğrenci Anketi-36] diyerek ifade etmişlerdir. Bu açıdan, öğretmen adaylarının mentörlerinin içerik bilgisi uzmanlıklarına fazlasıyla ihtiyaç duydukları ve onlara bu konuda güvendikleri görülmektedir. Ayrıca mesleki gelişim konusunda mentörlerinden destek görmeyi ve ementörlerinin mesleki gelişim anlamında yetkin olmalarını istemektedirler.

Bir diğer h-mentörlük özelliği ise kişisel özellikler teması altında iletişime açık, ilgili ve ilgisiz alt kategoriyle ifade edilmiştir. Öğretmen adayları mentörlerinin kişisel özellikleri üzerine fazla görüş bildirmemişlerdir. Çalışma boyunca girdikleri etkileşimlere dayalı olarak olumlu ve olumsuz görüşlerini belirtmişledir. Öğretmen adayları olumlu bir özellik olan iletişime açık olma konusunda şunları ifade etmişlerdir:

"Hocamızla olan diyaloğumuz çok iyiydi." [Öğrenci Anketi-21]

"Yanında rahat hissettirdi ve çok sıcak davrandl." [Öğrenci Anketi-24]

"Sorularımıza hızlı dönüş yaparak iletişimden kaynaklanan aksamaların önüne geçmiştir.” [Öğrenci Anketi-30]

Bir diğer olumlu özellik olarak, İngilizce okutmanlarının ilgili oldukları belirtilmiştir. öğretmen adayları "İlgili ve samimi olması herhangi takıldı̆̆ımız bir noktada kolaylıkla soru sorabilmemizi sağladı." [Öğrenci Anketi-24], "Bizden daha fazla emek harcadılar ve süreci eğlenceli hale getirdiler." [Öğrenci Anketi-31] ve "çok ilgilendiler" [Öğrenci Anketi-32] diyerek ifade etmişlerdir.

Olumlu bu özelliklerin yanında mentörlerinin ilgisiz olduğunu ifade eden ( $\mathrm{f}=4$ ) olumsuz görüşler de belirtilmiştir. H-mentörlüğün materyal geliştirme çalışmalarına katkısı olmadığını ifade eden bu görüşlere örnek olarak "Çok bir katkısı olmadı" [Öğrenci Anketi-2], "Kendi başımıza da yapabileceğimizi düşünüyorum ki genelde öyle oldu." [Öğrenci Anketi-41] 
verilebilir. Buna göre öğretmen adaylarının mentörlerin kişisel özelliklerini çalışmalarına katkısı açısından değerlendirdikleri belirtilebilir. Bu süreç içerisindeki tavırları iletişime açık olma ve ilgili olup olmamaları olarak ifade edilmektedir.

\section{Mentilerin H-Mentörlük Uygulaması Hakkındaki Görüşleri}

Öğretmen adaylarının Tablo 1'de sınıflandırılan h-mentör özelliklerine ilişkin görüşlerinin yanı sıra, h-mentörlük sürecinin kendilerine katkıları konusunda da görüşleri bulunmaktadır. $\mathrm{Bu}$ katkılar ise kolaylaştırma $(\mathrm{f}=9)$, işbirliği $(\mathrm{f}=6)$, öğrenme $(\mathrm{f}=6)$ ve mesleki gelişim $(\mathrm{f}=3)$ temalarında toplanmıştır. Bu ifadelere ilişskin örnekler ise şöyledir:

"Proje önerilerinde bulundukları için işimizi çok kolaylaştırdılar.” (kolaylaştırma) [Ö̆grenci Anketi-27]

"Grupça yeni bir ürün ortaya çıkarmanın keyfine vardık grup bilincim gelişti.”(işbirliği) [Öğrenci Anketi-10]

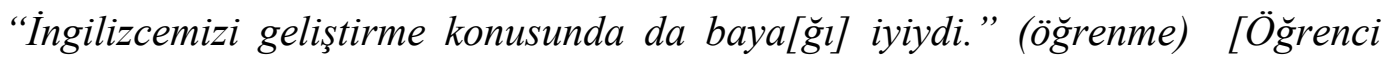
Anketi-16]

"Danışman hocalarımızla karşılıklı olarak yaptığımız fikir alışverişleri daha yaratıcı ve ögrenme açısından kalıcı olabilecek materyaller ortaya çıkarmamıza çok büyük bir katkı sağladığı düşüncesindeyim.” (mesleki gelişim) [Öğrenci Anketi7]

$\mathrm{Bu}$ görüşlerle birlikte öğretmen adaylarının süreçten faydalandıkları ve işbirliği içerisinde çalışma konusunda çeşitli deneyimler edindikleri görülmektedir. Ortalama mesleki deneyimleri 16 yıl olan mentörlerin, h-mentörlük uygulaması kapsamında da BT öğretmen adaylarının çalışmalarını kolaylaştırıcı ve mesleki gelişimlerini destekleyici bilgiler aktarabildikleri fark edilmektedir.

\section{Mentilerin H-Mentörlük Uygulaması Hakkındaki Görüşleri}

İngilizce mentörleri olan okutmanlar, BT öğretmen adayları ile gerçekleştirdikleri h-mentörlük çalışması hakkında bir başka ifade ile BT öğretmen adayları ile çalışma konusunda olumlu görüş ( $\mathrm{f}=4$ ) bildirmişlerdir. Sadece bir okutman bu konuda kararsız olduğunu ifade etmiştir. Buna ek olarak okutmanların tümü, bu tür bir çalışma tekrar edilirse, destek vereceklerini ve böyle bir çalışmada yer almak istediklerini ifade etmişlerdir. Bu işbirlikli çalışmanın katkıları konusunda belirttikleri görüşler ise şöyledir: 
“Her gün yaptı̆̆ımız ders anlatımı rutinimize hareketli anlar kazandırdı..daha önce de belirttiğim gibi değişik pc programların varlığının farkındalı̆̆ına vardık...uygulamasinı kismetse en yakın zamanda kendimiz de yapabilelim isterim..." [Mentör Anketi, 1]

"Yeni sunum teknikleri hakkında bilgi edindim ve farkındalığım gelişti. Değişik profilde öğrenci tanıdım. Sizleri tanıyıp çalışma imkanı buldum." [Mentör Anketi, 2]

“İki üç tane yeni ögretim platformu tanımış oldum.” [Mentör Anketi, 3]

"Biraz zaman alıcıyd,, programlarla öğrenciler ilgilendi buna rağmen düşündüğümüzde biraz daha uzun sürdü...ama eğlenceliydi... ” [Mentör Anketi, 4]

"Sanal sınıf uygulamalarını ve dijital materyal geliştirme araçlarını öğrenme imkanı sağladı.” [Mentör Anketi, 5]

$\mathrm{Bu}$ bağlamda mentörler, mentiler ile etkileşime girdikleri bu süreci kendi mesleki gelişimleri açısından faydalı olarak nitelemektedirler. Yeni araçlar ile değişik uygulamalar üretme fikri hakkında bilgi sahibi olduklarını belirtmektedirler. Mentör ve mentilerin görüşleri birlikte ele alındığında, hem mentörlerin hem de mentilerin materyal geliştirme sürecinde işbirliği içinde çalıştıkları, sürecin çalışmalarına olumlu katkılarda bulunduğu ve h-mentörlük uygulamalarına ilişkin ağırlıklı olarak olumlu görüşlere sahip oldukları görülmüştür.

\section{Tartışma, Sonuç ve Öneriler}

İngilizce öğretimine yönelik e-materyal tasarımında harmanlanmış bir mentörlük uygulaması olan bu çalışmada, menti rolündeki BT öğretmen adayları ve mentör rolündeki İngilizce okutmanlarının h-mentörlük sürecine ve bu sürecin katkılarına ilişkin görüşleri ele alınmıştır. Öğretmen eğitiminde yeterince örneğine rastlanmayan bu h-mentörlük uygulamasına ilişkin her iki paydaş grubunun da görüşlerinin genel olarak olumlu olduğu görülmüştür. Öğretmen adaylarına göre, İngilizce mentörlerinin bir ekip arkadaşı olarak kendilerine yardımcı ve yol gösterici olmaları ve mesleki anlamda da içerik uzmanı olarak destek vermeleri öne çıkan bulgulardır. Ek olarak öğretmen adayları, mentörlerinin kişisel açıdan iletişime açık ve çalışmalarıyla ilgili olduğunu da belirtmektedir. Bu özellikler, alanyazındaki çeşitli araştırma sonuçlarıyla desteklenmektedir (Arkün Kocadere ve Kızılkaya Cumaoğlu, 2015; Kılınç ve Alparslan, 2014; Özdemir, 2015). Bu açıdan, katılımcı mentörlerin çalışmadaki sorumluluklarını yerine getirdikleri düşünülmektedir.

Uygulamaya katılan öğretmen adaylarının önemli bir bölümü, h-mentörlüğün çalışmalarına olumlu katkı sağladığını belirtmiştir. Ek olarak, İngilizce mentörlerinin de tamamına yakını hmentörlük uygulamalarına yönelik memnuniyetlerini dile getirmişlerdir. Bu bulgular, hem Lamb ve Aldous'nun (2012) h-mentörlüğün mentilere deneyimlerini aktarmalarını sağlayarak 
olumlu etkileri olduğuna ilişkin bulgusunu hem de Murphy'nin (2011) h-mentörlüğün mentör ve mentiler üzerindeki olumlu katkıları bulgusunu desteklemektedir. Ayrıca, Thompson vd.nin (2010) çalışmasındaki gibi bu çalışmada da tüm mentörler, h-mentörlük uygulamalarına tekrar katılmak konusunda istekli olduklarını belirtmişlerdir. Bununla birlikte, bu çalışmada Cothran vd.nin (2009) e-mentörlük uygulamalarında karşılaştıkları teknik sorunlar ve e-mentörlüğün öğretmenlerin beklentilerini karşılamaması gibi sorunlar saptanmamıştır. Mentör ve mentilerin kendi sorumluluklarını yerine getirmelerinde hem elektronik ortamın hem de yüz yüze görüşmelerin birlikte işe koşulduğu harmanlanmış bir modelin, hem mentörler hem de mentiler tarafından olumlu karşılandığı görülmektedir. Thompson vd.nin (2010) de vurguladığ gibi, tümüyle elektronik iletişim etkisiz kaldığından, e-mentörlük uygulamalarında harmanlanmış formlara gereksinim duyulmaktadir.

Arkün Kocadere ve Kızılkaya Cumaoğlu'nun (2015) da belirttiği gibi, iyi uygulandığında, özellikle mentör - menti eşleştirmeleri doğru yapıldığında, mentörlük süreci hem mentör, hem de mentinin bireysel ve mesleki gelişimine katkı sağlar. Bu çalışmaya katılmada gönüllülük dışında bir ölçüt aranmadığı ve mentör-menti eşleştirilmesine ilişkin özel bir prosedür izlenmediği halde, bulgular genel olarak mentör ve mentilerin birlikte uyumlu çalıştıklarını göstermektedir.

Sonuç olarak, içerik uzmanlarının mentörlüğünde öğretim materyali geliştirmeyi amaçlayan bu uygulamada, h-mentörlük sürecinin işbirlikli ve disiplinler arası etkileşimli bir öğrenmeöğretme sürecinde hedefine ulaştığı düşünülmektedir. Bu bağlamda, araştırmacılara ve uygulayıcılara yönelik çeşitli öneriler sunmak mümkündür:

1- Veri toplama sürecinde, bu çalışmada uygulandığı gibi anket uygulamanın yanı sıra, gözlem ve görüşme gibi tekniklerle daha derinlemesine veri toplanabilir. Bu sayede, hmentörlük süreci daha detaylı irdelenebilir.

2- Bu çalışmadaki gibi işbirlikli gruplar ile mentör eşleştirmenin yanı sıra birebir hmentörlük uygulamaları yapılarak etkililik çalışmaları yürütülebilir.

3- $\mathrm{Bu}$ çalışmada az da olsa belirtilmiş olan, mentörlerin mentileriyle yeterince ilgilenmeyişleri gibi h-mentörlük sürecini olumsuz etkileyebilecek sorunları belirlemeye ve bu sorunları gidermeye dönük çalışmalar yapılması önerilmektedir.

4- Sadece betimsel değil, deneysel çalışmalar da yürütülerek h-mentörlük uygulamalarının çeşitli değişkenler üzerindeki etkileri çözümlenebilir.

5- BT öğretmen adaylarının yer aldığı bu çalışmaya benzer şekilde, uygulayıcılar diğer alan eğitimi bölümlerinde de uygun dersler seçerek, h-mentörlük çalışmaları yapabilir ve ulaşılan sonuçlar karşılaştırılabilir. 


\section{Kaynakça}

Anderson, E.M. ve Shannon, A.L. (1998). Toward a conceptualization of mentoring. Journal of Teacher Education, 39(1), 38-42.

Arkün Kocadere, S. ve Kızılkaya Cumaoğlu, G. (2015). Mentörlükten e-mentörlüğe. B. Akkoyunlu, A. İşman ve H.F. Odabaşı (Eds.), Eğitim teknolojileri okumaları 2015 içinde (ss. 493-511). Ankara: Ayrıntı Basım.

Bakioğlu, A. ve Göğüş, N. (2010). Elektronik mentörlük: Kariyer Girişi Evresi Öğretmenlerin Mesleğe Giriş Aşamasında Karşılaştıkları Sorunları Çözmeye Yönelik Bir Uygulama. V. Ulusal Eğitim Yöntemi Kongresinde sunulmuş bildiri. Gazi Üniversitesi, Antalya, Türkiye.

Bogdan, R.C. ve Biklen, S.K. (2007). Qualitative Research for Education: An Introduction to Theory and Methods. Boston: Allyn and Bacon.

Bradbury, L.U. ve Koballa Jr., T.R. (2008). Borders to cross: Identifying sources of tension in mentor-intern relationships. Teaching and Teacher Education, 24(8), 2132-2145.

Brescia W.F. (2002). Using a Telementoring Taxonomy in a World Wide Web Instructional Environment: A Case Study. Unpublished doctoral dissertation, Indiana University, Bloomington.

Clutterbuck, D. (2004). Everyone Needs a Mentor - Fostering talent in your. London: Charted Institute of Personnel.

Cothran, D., McCaughtry, N., Faust, R., Garn, A., Kulinna, P.H. ve Martin, J. (2009). EMentoring in Physical Education: Promises and Pitfalls. Research Quarterly for Exercise and Sport, 80(3), 552-562. doi: 10.1080/02701367.2009.10599593.

Creswell, J.W. (2003). Research Design: Qualitative, Quantitative and Mixed Methods Approaches. USA: Sage Publications.

EÜ-EBYS (Ege Üniversitesi- Elektronik Bilgi Yönetim Sistemi), (2016). Ege Üniversitesi Bilgi Paketi Ders Kataloğu.

http://ebys.ege.edu.tr/ogrenci/ebp/course.aspx?zs=1\&mod=1\&kultur=trTR\&program $=2935 \& \mathrm{did}=150225 \& \mathrm{mid}=633870 \& \mathrm{pmid}=15997$ adresinden 25.07 .2016 tarihinde alınmıştır. 
Fitzpatrick, J.L., Sanders, J.R. ve Worthen, B.R. (2004). Program Evaluation Alternative Approaches and Practical Guidelines. USA: Pearson Education.

Gormley, B. (2008). An application of attachment theory: Mentoring relationship dynamics and ethical concerns. Mentoring \& Tutoring: Partnership in Learning, 16, 45-62.

Gu, Q. ve Day, C. (2012). Challenges to teacher resilience: Conditions count. British Educational Research Journal, 1-23.

Hasselbring, T. S. ve Glaser, C. H. W. (2000). Use of computer technology to help students with special needs. The Future of Children - Children and Computer Technology, $10(2), 102-122$.

Hudson, P. (2016). Forming the Mentor-Mentee Relationship. Mentoring \& Tutoring: Partnership in Learning, 24(1), 30-43.

Kılınç, U. ve Alparslan, M.A. (2014). Yükseköğretimde mentörlük: Mentör ve Menti Bakış Açılarını Belirlemeye Yönelik Bir Uygulama. Yükseköğretim Dergisi, 4(2), 91-101.

Knouse, S.B. (2001). Virtual Mentors: Mentoring on the Internet. Journal of Employment Counseling, 38(4), 162-169.

Kocabaş, İ. ve Yirci, R. (2011). Öğretmen ve Yönetici Yetiştirmede mentörlük Mentörluğun Eğitimde Kullanılması, Ankara: Anı Yayıncılık.

Kuzu, A., Kahraman, M. ve Odabaşı, H.F. (2012). Mentörlükte Yeni Bir Yaklaşım: EMentörlük. Anadolu Üniversitesi Sosyal Bilimler Dergisi, 12(4), 173-184.

Lamb, P. ve Aldous, D. (2012). The role of E-Mentoring in distinguishing pedagogic experiences of gifted and talented pupils in physical education. Physical Education and Sport Pedagogy, 19(3), 301-319.

Murphy, W.M. (2011). From E-Mentoring to Blended Mentoring: Increasing Students' Developmental Initiation and Mentors' Satisfaction. Academy of Management Learning \& Education, 10(4), 606-622.

O'Neil, D.K. ve Gomez, L.M. (1996). Online mentors: Experimenting in science class. Educational Leadership, 54(3), 39-42.

Özdemir, S. (1997). Eğitimde örgütsel yenileşme. Ankara: Pegem Yayınları. 
Özdemir, T.Y. (2015). Electronic Mentorship with Mentee Perception. Turkish Online Journal of Qualitative Inquiry, 6(3), 45-66.

Özdemir, T.Y. ve Özan, M.B. (2013). E-mentörlük Sürecinin Mente Başarısına Etkisi. Bartın Üniversitesi Eğitim Fakültesi Dergisi, 2(1), 170-186.

Parsloe, E. ve Leedham, M. (2009). Coaching and mentoring: practical conversations to improve learning (second editon b.). London and Philadelphia: Kogan Page.

Single, P. ve Single, R. (2005). E-mentoring for social equity: Review of research to inform program development. Mentoring \& Tutoring: Partnership in Learning, 13(2), 301320. doi:10.1080/13611260500107481.

Single, P.B. ve Muller, C.B. (1999). Electronic mentoring: Issues to advance research and practice.

http://eric.ed.gov/?q=Electronic+mentoring\%3a+Issues+to+advance+research+and+p ractice. $+\&$ id=ED439683 adresinden 17.06.2016 tarihinde alınmıştır.

Thompson, L., Jeffries, M. ve Topping, K. (2010). E-mentoring for e-learning development. Innovations in Education and Teaching International, 47(3), 305-315, doi: 10.1080/14703297.2010.498182.

Wood, E.D. (2007). E-mentoring as a means to develop and retain expatriate. http://files.eric.ed.gov/fulltext/ED504860.pdf adresinden adresinden 17.06.2016 tarihinde alınmıştır.

Yıldırım, A. ve Şimşek, H. (2008). Sosyal bilimlerde nitel araştırma yöntemleri. (6. Baskı). Ankara: Seçkin Yayıncılık.

YTÜ-KM (Yıldız Teknik Üniversitesi Kariyer Merkezi), (2016).Yıldız Teknik Üniversitesi Kariyer Merkezi. http://www.orkam.yildiz.edu.tr/EMentorship.aspx adresinden 17.06.2016 tarihinde alınmıştır.

Yurdakul, B. (2015). Yapılandırmacılık. İçinde Ö. Demirel, (Ed.), Eğitimde yeni yönelimler (s. 39-65). Ankara: Pegem Akademi Yayıncılık. 